ВІСНИК

ОДЕСЬКОГО НАЦІОНАЛЬНОГО

МОРСЬКОГО УНІВЕРСИТЕТУ

№ 2 (65), 2021
HERALD

OF THE ODESSA NATIONAL

MARITIME UNIVERSITY № 2 (65), 2021

УДК 519.08

DOI 10.47049/2226-1893-2021-2-186-198

\title{
УПРАВЛІННЯ ОРГАНІЗАЦІЙНИМИ ЗНАННЯМИ В ОРГАНІЗАЦІЇ, ЩО ІННОВАЦІЙНО РОЗВИВАЕТЬСЯ
}

\author{
Лб. С. Чернова \\ к.т.н., доцент, доцент кафедри \\ «ІІнормаційні управляючі системи та технології»
}

Національний університет кораблебудування ім. адмірала Макарова

Анотація.У статті наводиться визначення організації, щуо інновачійно розвивається, розглядаються питання співвідношення стратегї бізнесу та інформачійних технологій.

Розглянуто питання ефективного управління системою знань, начілених на активізацію інновачійної діяльності, щзо сприяє активній позичї прачівників: необхідність ділитися знаннями, співпрачі при реалізаиії спільних проектів, мотивацією до саморозвитку.

Приводяться принциипи управління організацією, щзо інноваційно розвивається. У системах, побудованих на цих принщипах, на рівних повинні брати участь люди, чий інтелект володіс динамічністю, здатністю до прийняття рімень. В одну систему їх можуть об'єднати технологіï, що підтримують управління знаннями.

Представлена модель системи управління знаннями, навколо ииклу знань у вигляді «знаннєвих процесів»: виявляти, створювати, зберігати, обмінювати, застосовувати. Змістом управління знаннями є забезпечення поширення знань, як з зовнішнього, так $i$ з внутрішнього оточення. Знання повинне бути «корисним», тобто для конкретної організаиії має иінність те знання, яке сприяє зростанню його інноваційної активності і здатне наповнити змістовним сенсом «ланцюжок знань».

Ключові слова: управління знаннями, організація, що інноваційно розвивається, ланцюжсок знань, стратегія персонізачії $і$ кодифікаиії.

\section{УДК 519.08}

DOI 10.47049/2226-1893-2021-2-186-198

\section{УПРАВЛЕНИЕ ОРГАНИЗАЦИОННЫМИ ЗНАНИЯМИ В ИННОВАЦИОННО РАЗВИВАЮЩЕЙСЯ ОРГАНИЗАЦИИ}

\author{
Лб. С. Чернова \\ к.т.н., доцент, доцент кафедры \\ «Информационно управляющие системы и технологии»
}

Нацииональный университет кораблестроения им. адмирала Макарова

() Чернова Лб.С., 2021 
Аннотация. В статье приводится определение инновацийно развиваюшейся организаџии, рассматриваются вопросы соотношения стратегии бизнеса и информачионных технологий.

Рассмотрены вопросы эффективного управления системой знаний, начеленных на активизачию инновационной деятельности, которая способствует активной позичии работников: необходимость делиться знаниями, сотрудничества при реализачии совместных проектов, мотивачией к саморазвитию.

Приводятся принципь управления инновационно развивающейся организацией. В системах, построенных на этих принципах, на равных должны участвовать люди, чей интеллект обладает динамичностью, способностью к принятию решений. В одну систему их могут объединить технологии, которые поддерживают управление знаниями.

Представленная модель системь управления знаниями, вокруг иикла знаний в виде «знаниевых прочессов»: выявлять, создавать, сберегать, обменивать, применять. Содержанием управления знаниями является обеспечение распространения знаний, как с внешнего, так и с внутреннего окружения. Знание должно быть «полезным», то есть для конкретной организации имеет ценность то знание, которое способствует росту его инновачионной активности и способно наполнить содержательным смыслом «цепочку знаний».

Ключевые слова: управление знаниями, организачия, инновационно развивается, цепочка знаний, стратегия персонизаџии и кодификаичии.

\title{
UDC 519.08 \\ DOI 10.47049/2226-1893-2021-2(65)-186-198
}

\section{MANAGEMENT OF ORGANIZATIONAL KNOWLEDGE IN AN INNOVATIVE DEVELOPMENTAL ORGANIZATION}

\author{
Lb. S. Chernova
}

Ph.D., Associate Professor,

Associate Professor of «Information Control Systems and Technologies»

$$
\text { National University of Shipbuilding. Admiral Makarov }
$$

Abstract.The article provides a definition of an innovatively developing organization, examines the relationship between business strategy and information technology.

The issues of effective management of the knowledge system, aimed at enhancing innovation, which contributes to the active position of employees: the need to share knowledge, cooperation in the implementation of joint projects, motivation for self-development are considered. 
The principles of managing an innovatively developing organization are given. In systems built on these principles, people whose intelligence has dynamism and the ability to make decisions should participate on an equal footing. Technologies that support knowledge management can combine them into one system.

A model of a knowledge management system is presented, built around the knowledge cycle in the form of "knowledge processes»: to identify, create, save, exchange, apply. The content of knowledge management is to ensure the dissemination of knowledge, both from the external and from the internal environment. Knowledge should be «useful», that is, for a particular organization, that knowledge is valuable that contributes to the growth of its innovative activity and is able to fill the "chain of knowledge» with meaningful meaning.

Keywords: knowledge management, innovative development organization, knowledge chain, personalization and codification strategy.

Вступ. Поняття організації, що інноваційно розвивається, з'явилося не випадково - це об'єктивно необхідно організаціям майбутнього, щоб вижити на новому витку еволюційної гонки. Те, що сьогодні відбувається в економіці під впливом нових засобів комунікації, нагадує перехід 3 крейдяного в третинний період, коли в короткий за геологічними мірками період зникли динозаври і їх місце зайняли більш динамічні ссавці. Нові підприємства відрізняє перехід від повільного прогнозування до реактивного попередження несподіванок. Змінюється загальний стиль мислення: традиційний конвергентний стиль (convergent thinking), що передбачає пошук одного кращого або правильного рішення, поступається дивергентному, або синтетичному (divergent thinking), коли метою $\epsilon$ пошук різних відповідей на безліч питань. Відбувається відмова від строгих структур на користь структур, що допускають елементи безладу, нематеріальні активи (наприклад, інформація) стають важливіше матеріальних, самоврядування стає важливіше підпорядкування, а створення нових знань важливіше, ніж використання старих. Ці зміни призводять до ряду наслідків, які можна назвати принципами створення організації, що інноваційно розвивається.

У швидко мінливому світі вибір однієї-єдиної стратегії стає неможливий, і перспективніший підхід, який отримав назву «сценарне планування» і дозволяє враховувати невизначеність майбутнього. Цей тип аналізу, його ще називають сценарним мисленням або сценарним аналізом, поєднує зумовлені елементи (predetermined elements) 3 найбільш суттєвими невизначеностями (key uncertainties) при виробленні сценаріїв майбутнього. Сценарне планування розглядає всі сценарії як однаково можливі в майбутньому - організація повинна розробляти плани, але не може будувати свою діяльність за планом. 
Інформаційні технології (IT) в їх нинішньому вигляді реалізують запрограмовану логіку, яка дозволяє вибирати щось зі збережених даних і по-іншому їх інтерпретувати, але такого роду логіка зазвичай не призводить до якихось нових умовиводів. Інакше кажучи, хоча технології і називаються інформаційними, вони не дозволяють витягати нову інформацію і тим більше нові знання - такими здібностями володіє тільки людина. Істотно великими можливостями мають підходи, де засобами IT створюються групи фахівців, об'єднаних спільною справою (Community of Practice). Засновниками СоР визнані Джин Лейв і Етьєн Венгер, які розглядають IT як інструмент для об'єднання, яке може носити неформальний i частково формальний характер. Натяки на використання комп'ютерів в цій якості можна знайти в працях таких основоположників сучасної комп'ютерної галузі, як Ванневар Буш, Джозеф Ликлайдер і Даг Енгельбарт, написаних десятиліття назад.

Відмова від адміністративно-командних принципів (command and control) на користь підходу sense and respond (буквально «відчути і відреагувати») передбачає гнучке реагування на потреби ринку і забезпечення якості, яке можна інтерпретувати як здатність організації бачити ситуацію (organizational vision). Модель sense and respond має велику здатність до адаптації, масштабованість і іншими властивостями, необхідними для створення динамічного підприємства. Область дії моделі не обмежується бізнесом. Наприклад, корпорація IBM опублікувала звіт Transforming the military through sense and respond, в якому показано, що ця модель відповідає вимогам сучасної армії, оскільки в їі основі лежать координація многоагентних модулів, здатних реагувати на зміни, допущення про нечітких умовах і недостовірних відомостях, створення мереж з автономних модулів, об'єднаних спільною метою. Дані спостереження не залишилися без уваги; наприклад, Пентагон ухвалив за ним кілька рішень, в тому числі про створення управління Network-Centric Operations, про використання методів sense and respond в логістиці і загальному зміні військової культури.

Очевидно, що в системах, побудованих на перерахованих принципах, на рівних повинні брати участь люди, чий інтелект володіє динамічністю, здатністю до прийняття рішень, не потребує попереднього програмування, але обмежений тим, що може утримувати в пам'яті одночасно не більше семи об'єктів, і машини, здатні тупо перемелювати гігантські обсяги даних.

В одну систему їх можуть об'єднати технології, що підтримують управління знаннями (Knowledge Management, KM), в цьому і полягає їх головна інтегруюча роль. КМ може виступити в ролі парасольки, під яким будуть зібрані окремі камені-технології. В такому випадку класична картинка управління по зворотного зв'язку (рис. 1) може трансформувати в іншу (рис. 2). Участь людини дозволяє заповнити зазор між моделлю і реальним життям. 


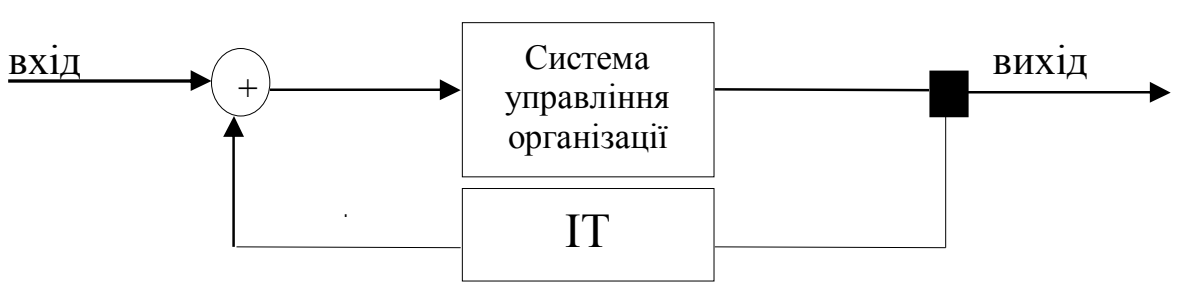

Рис. 1. Традииійна схема управління організаиії

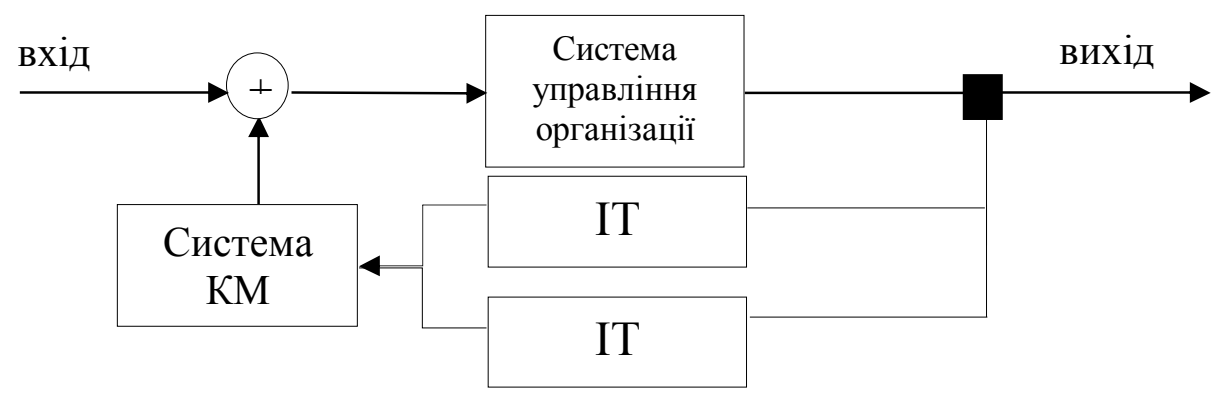

Рис. 2. Система управління організації з використанням системи КМ

Завдання дослідження. Побудова технології управління організаційним знанням, як методологія формування організації, що інноваційно розвивається.

Розгляд моделі системи управління знаннями, побудованої навколо циклу знань у вигляді «знаннєвих процесів» в залежності від бачення стратегії і місії організації.

Визначення поняття «цінність знання» для організації, яка сприяє зростанню його інноваційної активності і наповненням змістовним сенсом «ланцюжка знань».

Аналіз літератури. Провівши аналіз досягнень вчених в сфері управління знаннями $[1 ; 2 ; 3 ; 4 ; 5 ; 6 ; 7 ; 8]$, встановлено, що в методології управління проектами недостатньо вивчений компонент, пов'язаний 3 управлінням знаннями організацій, що інноваційно розвиваються.

Викладення основного матеріалу. Підвищення ефективності управлінської діяльності організації, що дозволяє домогтися розширення інноваційної активності, є розвиток здатності використовувати знання, створені у зовнішньому середовищі і поширювати їх всередині організації. Це пов'язано $з$ тим, що «на конкурентоспроможність підприємств в майбутні десятиліття все більший вплив буде надавати їх здатність ідентифікувати, накопичувати і розвивати знання i, використовуючи ключові 
чинники успіху на ринку, створювати інновації, а потім довготривалі стійкі конкурентні переваги» [9]. «Створення знань-постійні інноваціїконкурентоспроможність» - це обгрунтовано в [10]. «Вихідним компонентом інновацій $€$ саме нові знання: про цілі, засоби і результати діяльності $[11] \gg$.

В основі інновації лежить нове знання, яке отримало практичне втілення, тому менеджмент, орієнтований на генерацію і активізацію інновацій, значну увагу приділяє управлінню процесом виявлення, поширення і впровадження знань, іншими словами - управління знаннями.

Оскільки первинним чинником в процесі матеріального виробництва і розподілу є керуюча інформація, яка викликає потік творчої, споживаної енергії i, як наслідок, матеріальний потік з усіма його перетвореннями, то не дивно, що багато сучасних теорій фірм базується на первинності знань як базового ресурсу. «Управління знаннями» - найбільш часто вживаний термін в даній області, хоча авторами він трактується і розкривається по різному. Ключові проблеми та завдання в цьому нап-рямку, досить широко модифікується. Від оптимізації «управління інфор-мацією» до формування «системи управління знаннями», від проблем навчання персоналу до проблем подолання «когнітивної інерції» $\mathrm{i}$ т.д. Три чверті з числа опитаних європейських лідерів бізнесу, будучи ознайом-лені 3 декількома визначеннями «управління знаннями», проголосували за таке його визначення: «Це - сукупність процесів, які керують створенням, розповсюдженням, обміном та використанням знань для досягнення цілей організації».

Знання як об'єкт управління характеризуються рядом особливостей:

- неявні (неформалізовані, неусвідомлені) знання представляються як більш цінні для організації, ніж явні (формалізовані, усвідомлені). Останні більшою мірою відповідають категорії «інформація» і можуть порівняно легко тиражуватися і поширюватися, в тому числі і серед конкурентів;

- знання створюється на основі взаємодії колективу людей в ході їх цілеспрямованої діяльності, створюється людиною і є іiї невід'ємною частиною;

- «знання, здебільшого існує лише в практичному аспекті», тобто на відміну від інформації озброюють носіїв здатністю адекватно відповідати на зовнішні виклики.

3 метою стимулювання інноваційної активності, діяльність у сфері управління знаннями повинна пронизувати всі структури організації, сприяти виявленню цінного знання кожним співробітником. Якщо мова йде про ідентифікацію знань необхідних для досягнення конкурентних цілей, то $є$ небезпека звести управління знаннями до управління інформаційними ресурсами, тоді як управління знаннями має сприяти, в тому числі, генеруванню самих цілей. В першу чергу шляхом виявлення знань 
у зовнішньому середовищі і створення організаційних умов для їх ефективного поширення. Іншими словами одне 3 ключових завдань управління знаннями полягає в тому, щоб інформаційні потоки у зовнішньому і внутрішньому середовищі могли трансформуватися в нове знання. «УПравління знаннями передбачає пошук інноваційних рішень при виникненні несподіваних завдань».

Найбільш відомим підходом до побудови типології стратегій управління організаційним знанням, являється виділення стратегій персоналізації і кодифікації, в основі кожної з яких переважний тип використовуваного знання: особове і кодифікаційне знання, відповідно. Безумовно, ця класифікація, незважаючи на iї фундаментальність, не може відбити усе різноманіття підходів до стратегічного управління знаннями в організаціяX.

Стратегічні альтернативи управління організаційним знанням можуть бути представлені в сукупності наступних двох вимірів:

- пріоритетний процес управліннями знаннями в організації (створення або обмін знаннями);

- місце для розташування пріоритетного джерела знань (усередині або поза організацією).

Обидва виміри допускають варіант поєднання характеристик, оскільки і внутрішні, і зовнішні джерела знань, а також процеси створення і обміну знаннями не $є$ взаємовиключаючими. Переважним $є$ поєднання процесів генерації і обміну знаннями і деякий баланс внутрішніх $\mathrm{i}$ зовнішніх джерел знань.

Комбінація вказаних вимірів дозволяє оцінити поточну ситуацію і бажану стратегічну перспективу в області управління знаннями. Внутрішні знання, знаходячись в головах співробітників, організаційних базах даних, управлінської документації, більше специфічні, унікальні і тим значиміші для організації. Джерелами зовнішніх знань можуть бути постачальники, споживачі, конкуренти, консалтингові, інформаційні фірми, науково-технічна література, а також інституціональні джерела: наукові організації академічного і галузевого профілю, університети i інші вищі учбові заклади. Зовнішні знання, як правило, абстрактніші, доступніші (і конкурентам, у тому числі) i, проте, більш дорожчі в експлуатації.

Проведений аналіз існуючих моделей управління знаннями як системи взаємозв'язаних процесів трансформації знань в організації, численних підходів до встановлення складу і змісту процесів управління знаннями в організаціях дозволяє встановити пріоритетний характер процесів генерування знань і обміну ними.

Створення і обмін знаннями служить ключовими процесами управління ними і в той же час характеризуються принципово різними практиками. Процеси створення знань носять інноваційний характер, процеси обміну знаннями - реплікаційні. 
У будь-якій галузі можна виділити декілька типів інноваційноактивних компаній:

1. Стратегічні новатори - розглядають масштабні довгострокові проекти науково-дослідних і дослідно-конструкторських робіт в якості основного ресурсу конкурентоспроможності. Як правило, ці компанії $\epsilon$ основним джерелом радикальних інновацій для інших компаній галузі.

2. Непостійні (періодичні) новатори - ведуть власні дослідження і розробки $з$ потреби або за сприятливих умов, але не розглядають створення нововведень ключовим, стратегічним завданням компанії.

3. Модифікатори технологій - не ведуть повного циклу науководослідних і дослідно-конструкторських робіт, але використовують інженерні розробки для удосконалення своїх продуктів і процесів.

4. Користувачі технологій - ведуть інноваційну діяльність шляхом адаптації технологічних рішень, розроблених іншими організаціями.

Підприємства, орієнтовані на використання внутрішніх джерел знань, реалізують оборонну стратегію, приділяючи особливу увагу збереженню і захисту внутрішніх знань.

Організації, що широко використовують на додаток до внутрішніх ще й зовнішні знання $є$ найбільш конкурентоздатними, більше адаптивними до динамічних змін довкілля, у тому числі до зміни переваг споживачів.

«Знання є невід'ємним атрибутом людини, його свідомості, а не відокремленим фактором виробництва» [12]. Тому управління знаннями нагадує ірраціональне прагнення об'єднати співробітників в єдиний колективний розум, який дозволяє подолати дискретність знань.

Пізнання в команді - це набагато більше, ніж просто результат їх розуміння. При певних умовах в колективі досягається, в когнітивному сенсі, синергічний ефект. 3 метою активізації інноваційного процесу необхідно визначити ці умови і формувати їх.

На рис. 3 представлена модель системи КМ, створена навколо циклу знань у вигляді «знаннєвих процесів»: виявляти, створювати, зберігати, обмінювати, застосовувати [13]. В залежності бачення стратегії i місії організації (ядро моделі) формуються «шари» моделі. «Шар» моделі - акселератори (те, що допомагає стимулювати і прискорювати процеси управління знаннями) - «люди - процеси - технології - лідерство».

Три зовнішні «шари» - це результати: те, що дає нам ефективно працююча система КМ. Причому відображено взаємозв'язок цих результатів: за допомогою процесів КМ ми створюємо інновації та організовуємо безперервне навчання фахівців, що веде до зростання індивідуальних, командних і організаційних можливостей і соціального потенціалу, а ті, в свою чергу, призводять до зростання продуктивності, якості та прибутковості організації. 


\begin{tabular}{c|c} 
ВІСНИК & HERALD \\
ОДЕСЬКОГО НАЦІОНАЛЬНОГО & OF THE ODESSA NATIONAL \\
МОРСЬКОГО УНІВЕРСИТЕТУ & MARITIME UNIVERSITY \\
№ 2 (65), 2021 & № $2(65), 2021$ \\
\hline
\end{tabular}

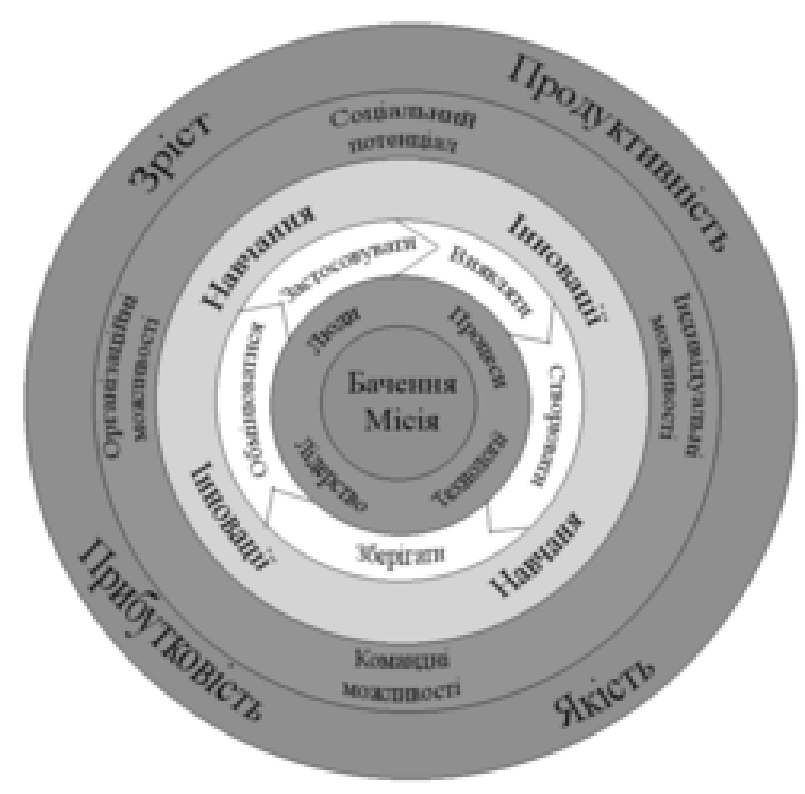

Рис. 3. Модель системи КМ

Змістом управління знаннями є забезпечення поширення знань, як iз зовнішнього, так і з внутрішнього оточення (неявне знання). Знання повинно бути «корисним», тобто для конкретної організації має цінність те знання, яке сприяє зростанню його інноваційної активності і здатне наповнити змістовним сенсом «ланцюжок знань» (рис. 4).

\begin{tabular}{|c|c|c|c|}
\hline $\begin{array}{l}\text { Внутрішня } \\
\text { обізнаність }\end{array}$ & $\begin{array}{c}\text { Внутрішня } \\
\text { реакція }\end{array}$ & $\begin{array}{c}\text { Зовнішня } \\
\text { реакція }\end{array}$ & $\begin{array}{c}\text { Зовнішня } \\
\text { обізнаність }\end{array}$ \\
\hline $\begin{array}{c}\text { Загальна } \\
\text { обізнаність } \\
\text { про сильні } \\
\text { і слабкі } \\
\text { сторонни } \\
\text { організації } \\
\text { незалежно } \\
\text { від ієрархічної } \\
\text { та функціо- } \\
\text { нальної } \\
\text { приналежності } \\
\text { співробітників }\end{array}$ & $\begin{array}{c}\text { Здатність } \\
\text { оперативно } \\
\text { знаходити } \\
\text { навички, } \\
\text { керуючись } \\
\text { внутрішньою } \\
\text { обізнаністю } \\
\text { про доступні } \\
\text { ресурси, запити } \\
\text { ринку і існуючі на } \\
\text { ринку можливості }\end{array}$ & $\begin{array}{c}\text { Високий } \\
\text { рівень } \\
\text { моторності, } \\
\text { постійна } \\
\text { готовність вести } \\
\text { діалог з ринком } \\
\text { на його } \\
\text { умови, навіть } \\
\text { якщо сам ринок } \\
\text { не здатний } \\
\text { сформулювати } \\
\text { правила гри }\end{array}$ & $\begin{array}{c}\text { Усунення } \\
\text { перешкод } \\
\text { між ринком } \\
\text { і власною } \\
\text { схильністю } \\
\text { до новаторства } \\
\text { для встановлення } \\
\text { реальних взаємин } \\
\text { з реальними } \\
\text { і потенційними } \\
\text { клієнтами }\end{array}$ \\
\hline
\end{tabular}

Рис. 4. Ланиюжок знань як послідовність взаємодій, щзо формує інновачійний ичикл організаиії 
Ефективне управління системою знань, націлене на активізацію інноваційної діяльності, має на увазі наявність адекватних елементів кадрової політики, що сприяють активній позиції працівників: потребою ділитися знаннями, співпраці при реалізації спільних проектів, мотивацією до саморозвитку. Сприяти такій позиції можуть, на наш погляд, нижченаведені заходи.

- Створення (або підтримка існуючих) неформальних груп, в рамках яких можлива генерація i обробка організаційно важливих ідей, бачення внутрішньо-організаційної проблеми та шляхи їх вирішення 3 точки зору пересічних співробітників. Такі групи стають свого роду простором для інтенсивної взаємодії персоналу; при цьому такого роду неформальні групи отримують офіційну підтримку у вигляді виробничих приміщень, матеріально-технічних ресурсів і т.п.

- Поступовий відхід від моделей «знизу-вгору» і «зверху-вниз» до моделі «з центру-вниз-вгору». Дана модель може сприяти виявленню інноваційного потенціалу, закладеного в співробітниках. Шляхом максимального зближення вищого керівництва (постановка завдань, бачення) i рядових співробітників (пропозиція шляхів досягнення) передбачається зменшити «розрив між мрією і реальністю». Досягається це, в першу чергу, завдяки зусиллям менеджерів середньої ланки, і саме вони стають «сполучною ланкою» між вищим і нижчим рівнем. Середня ланка управління набуває тут ключове значення тому, що створення цінних для фірми інновацій досягається шляхом синтезу діяльності вищого керівництва i рядових співробітників та багато в чому все залежить від того, наскільки ефективним $\epsilon$ цей зв'язок, що реалізується менеджерами середньої ланки.

- Впровадження гнучких механізмів винагороди, що стимулюють обмін знаннями. При цьому необхідно виробити ясні критерії стимулювання за активність у сфері поширення знань.

- Чітка позиція керівництва, його ставлення до питань розвитку та навчання співробітників. Позиція керівництва може сприйматися, як свого роду ступінь організаційного наміру домогтися успіху в сфері управління знаннями.

Слід також зазначити, що здатність соціально-економічної системи до навчання ( «самонавчання») обумовлюється наявністю «культуральних знань», які можна розглядати з таких позицій:

- словникові знання: визначення і класифікація об'єктів і подій (процедурні);

- інструктивні знання: інформація про те, як це зробити (описові); (розпорядчі);

- методичні знання: інформація про те, як це зробити якнайкраще

- аксіоматичні знання: фундаментальні переконання або базові причини, які не можуть бути зведені до чогось іншого. 
Будь-які заходи, спрямовані на формування системи КМ, повинні бути узгоджені $з$ наявним станом культуральних знань, тобто знань на рівні культури або розподільного розуміння. Усередині організації всі процеси проходять крізь призму людської свідомості (свого роду іманентний суб'єктивізм), і то, який напрямок вони отримають, залежить від ефективності управління, взаємодії між групами, особистостями. Такі категорії як «мета» і «засоби» повинні мати загальноорганізаційну, загальновизнану, єдину цінність.

Таким чином, в рамках управління знаннями тісно переплітаються процеси управління інформаційними ресурсами, розвитку та оцінки персоналу, формування адекватного «культурального» середовища (організаційної культури). Інтегровані в єдину стратегію управління знаннями ці процеси $\epsilon$ серйозним внутрішнім фактором активізації інноваційної діяльності на підприємстві.

Висновок. Формування інноваційної стратегії управління знаннями дозволить організації набути ознак організації, що навчається, тобто здатної до сприйняття і фільтрації навіть слабких сигналів, але тих які $\epsilon$ індикаторами змін. Саме чутливість до неявних сигналів, які майже на рівні «інтуїції» дозволяють вловити, де інновація буде успішною, власне і робить організацію інноваційною.

\section{ЛІТЕРАТУРА}

1. Мариничева, М. Управление знаниями на $100 \%$. Путеводитель для практикантов. М.: Альпина Бизнес Букс. 2008. 320 с.

2. Коулоулос, Т.Т., Фраппаоло, К. Управление знаниями / Пер. с англ. М., 2008. 224 c.

3. Тесля, Ю.М., Хлевна, Ю.Л., Егорченкова, Н.Ю. Управління знаннями в мета-методології управління проектами // Управління проектами та розвиток виробництва: Зб. наук. праць. Луганськ: Вид-во СНУ ім. В. Даля, 2016. № 4 (60). С.53-61.

4. Бушуев, С.Д., Бушуева, Н.С. Методология управления проектами как универсальная модель знаний. // Управління проектами та розвиток виробництва: 3б. наук. праць. Луганськ: Вид-во СНУ ім. В. Даля, 2003. № 3 (8). С.5-12.

5. Бабаев, И.А. Инструменты моделирования знаний в управлении проектами // Управління проектами та розвиток виробництва: Зб. наук. праџь. Луганськ: Вид-во СНУ ім. В. Даля, 2004. № 2 (10). C.10-24.

6. Глубокова, Е.Н. Управление знаниями как основа построения образовательного прочесса в современном университете / Е.Н. Глубокова // Известия Российского государственного педагогического университета им. А.И. Гериена. СПб., 2009. № 100. C.48-56. 
ВІСНИК

ОДЕСЬКОГО НАЦІОНАЛЬНОГО

МОРСЬКОГО УНІВЕРСИТЕТУ

№ 2 (65), 2021
HERALD

OF THE ODESSA NATIONAL

MARITIME UNIVERSITY № 2 (65), 2021

7. Силов, В.Б. Принятие стратегических решений в нечеткой обстановке: Монография. М.: ИНПРО-РЕС, 1995. 228 с.

8. Смирнова, Е.Е., Надеждин Е.Н. Нечеткая когнитивная модель механизма формирования профессиональных компетеничий будущего бакалавра экономики // Информащия образования и науки. 2016. № 1(29). С. 175-184.

9. Шевченко, С.Ю. Инновационное развитие и конкурентоспособность: методология обоснования стратегических решений. СПб.: Изд-во СПБУЭФ, 1996. 311 c.

10. Нонака Икуджиро, Такеучи Хиротак. Компания - создатель знания. Зарождение и развитие инноваций в японских фирмах / Пер. с англ. М.: 3АО «Олимп Бизнес», 2003. 384 с.

11. Лапин, Н. Целенаправленное воплощение знаний в инновациях // Проблемь теории и практики управления. 2007. № 3. C. $105-114$.

12. Логачев, В.А., Жернов, Е.Е. Знание в новейших теориях фирмbl. ЭКО. 2007. № 9.

13. APO Knowledge Management Facilitators Guide / Asian Productivity Organization, Tokyo 113 - 0033, Bunkyo-ku, 2020 (www.apo-tokyo.org)

\section{REFERENCES}

1. Marinicheva, M. Knowledge management by $100 \%$. Guide for trainees. M.: Alpina Business Books. 2008. 320 p.

2. Couloulos, T.T., Frappaolo, K. Knowledge management / Per.with English. M., 2008. 224 p.

3. Tesla, Yu.M., Khlevna, Yu.L., Egorchenkova, N.Yu. Knowledge management in project management meta-methodology // Project management and production development: Coll. Science works. Lugansk: published by SNU V. Dalya, 2016. № 4 (60). P.53-61.

4. Bushuev, S.D., Bushueva, N.S. Project management methodology as a universal model of knowledge // Project management and production development: Coll. Science works. Lugansk: published by SNU V. Dalya, 2003. № 3 (8). P.5-12.

5. Babaev, I.A. Knowledge modeling tools in project management // Project management and production development: Coll. Science works. Lugansk: published by SNU V. Dalia, 2004. № 2 (10) P.10-24

6. Glubokova, E.N. Knowledge management as a basis for building an educational process in a modern university / Glubokova EN // Izvestiya Rossiiskogo gosudarstvennogo pedagogicheskogo universiteta im. A.I. Herzen. SPb., 2009. № 100. P.48-56. 
ВІСНИК

ОДЕСЬКОГО НАЦІОНАЛЬНОГО

МОРСЬКОГО УНІВЕРСИТЕТУ
HERALD

OF THE ODESSA NATIONAL

MARITIME UNIVERSITY № 2 (65), 2021

7. Silov, V.B. Making strategic decisions in a vague situation: a monograph. M.: INPRO-RES, 1995. - 228 p.

8. Smirnova, E.E., Nadezhdin, E.N. Fuzzy cognitive model of the mechanism of formation of professional competencies of the future bachelor of economics // Information of education and science. 2016. № 1 (29). 175-184.

9. Shevchenko, S.Yu. Innovative development and competitiveness: a methodology for substantiating strategic decisions. SPb: Publishing house SPBUEF, 1996. $311 \mathrm{~s}$.

10. Nonaka Ikujiro, Takeuchi Hirotak. The company is a creator of knowledge. The origin and development of innovations in Japanese firms/Per. from English. M.: CJSC «Olymp Business», 2003. $384 \mathrm{~s}$.

11. Lapin, N. Purposeful embodiment of knowledge in innovation // Problems of theory and practice of management. 2007. № 3. S. 105-114.

12. Logachev, V.A., Zhernov E.E. Knowledge in the latest theories of the firm. IVF. 2007. № 9.

13. APO Knowledge Management Facilitators Guide / Asian Productivity Organization, Tokyo 113-0033, Bunkyo-ku, 2020 (www.apo-tokyo.org)

Стаття надійшла до редакиії 04.02.2021

Посилання на статтю: Чернова Лб.С. Управління організаційними знаннями в організації, що інноваційно розвивається // Вісник Одеського національного морського університету: Зб. наук. праць, 2021. № 2(65). С. 186-198. DOI 10.47049/ 2226-1893-2021-2-186-198.

Article received 04.02.2021

Reference a JournalArtic: Chernova Lb. S. Management of organizational knowledge in an innovative developmental organization // Herald of the Odessa national maritime university. 2021, № 2(65). C. 186-198. DOI 10.47049/2226-18932021-2-186-198. 